\title{
Soil Infiltration Management on Perspective of Sustainable Development Goals (SDGs)
}

\author{
Harry Susanto $^{1 *}$, Eko Ganis Sukoharsono ${ }^{2}$, Bambang Hendroyono ${ }^{3}$, Amin Setyo Leksono ${ }^{4}$ \\ ${ }^{1}$ Doctoral Program of the Environmental Science Doctoral Program, Brawijaya University Malang \\ City, East Java 65145, Indonesia; and Lecturer at the University of Sunan Bonang, Tuban Regency, \\ East Java 62315, Indonesia. \\ ${ }^{2}$ Department of Accounting, Brawijaya University, Malang City, East Java 65145, Indonesia, \\ ${ }^{3}$ Secretary General of the Indonesian Minister of Environment and Forestry, \\ ${ }^{4}$ Department of Biology, Brawijaya University, Malang City, East Java 65145, Indonesia,
}

Received: November 23, 2020. Revised: May 9, 2021. Accepted: June 3, 2021. Published: June 4, 2021.

\begin{abstract}
UB Forest is a Forest Area with Special Purpose (KHDTK) located on the slopes of Mount Arjuno. Before being managed by the University of Brawijaya, there was a change in land cover from natural forest to pine and mahogany production forest. This change was a result of the PHBM (Collaborative Forest Management) contract agreement between Perhutani and the community to carry out agricultural management. The input of organic matter with different quality and quantity will affect the organic matter content and in turn will affect the physical properties of the soil such as bulk density, density and soil porosity. Soil porosity is a physical property of soil that affects soil infiltration. The objective of this study is to identify and analyze the management of Forest Areas and to build a green economy model in the management of KHDTK University of Brawijaya Forest in the Perspective of Sustainable Development Goals (SDGs) in Malang Regency. The method used in this research is qualitative research. Implementation of green economy model in the management of KHDTK University of Brawijaya Forest in the concept of forestry sector contribution related to climate change; the concept of sustainable forest resource management; and the concept of environmental service providers. The results of the infiltration measurement using the single ring infiltrometer method can better describe the infiltration that occurs in the soil. The highest soil infiltration is in protected areas with a soil infiltration rate of $131.33 \mathrm{~cm} / \mathrm{hour}$ (single ring infiltrometer). Meanwhile, the lowest infiltration was found in the pine production forest plot overlaid with seasonal crops with a soil infiltration rate of $12 \mathrm{~cm} /$ hour (single ring infiltrometer).
\end{abstract}

Keywords - Green Economy Model, Soil Infiltration, UB Forest, and Sustainable Development Goals (SDGs).

\section{INTRODUCTION}

Recognizing the importance forests, the management of University of Brawijaya Forest in the Karangploso sub regency of Malang Regency needs to prioritize the principles of sustainable land management and ensure the community's welfare in the UB Forest area. Referring to the Decree of the Minister of Environment and Forestry of the Republic of Indonesia Number: 676 / MenLHK-Setjen / 2015 UB Forest has a function as a Forest Area with Special Purpose (KHDTK) managed by University of Brawijaya with a forest area of 544.74 hectares. KHDTK- University of Brawijaya or better known as UB Forest is an example of a forest ecosystem in Malang Regency.

The existing reality of UB Forest management is by preserving the conservation of protected forest and utilizing space for non-forest needs by planting coffee plants in production forest area. However, the existing condition is that coffee production in UB Forest has not been able to improve community's welfare in the economic sector. Most of the community in the UB Forest area prefer to work as agricultural laborers on forest area managed by Perhutani. It means that the natural resources in UB Forest have not been able to provide maximum livelihood within the forest. For this reason, it is necessary to develop the management of UB Forest in a sustainable manner so that the implementation of green economy in the forestry sector of UB Forest which has multifunction forests in maintaining the diversity of life and livelihood aspects within the forest can be manifested. Thus, investments made in natural capital in the form of protection and good management can be made by establishing a protected area as well as an area for good productive management in concession areas, along with the recognition of the rights of traditional communities in managing their environment and natural resources. For that, building a green economy model in the management of UB Forest with the perspective of SDGs is 
an alternative in overcoming the challenges of sustainable development which must include three aspects, namely economic, social and environmental.

This research was carried out in order to build a Green Economy model in the management of UB Forest based on the SDGs perspective in order to increase the potential in the management of UB Forest. Thus, the implementation of green economy in the forestry sector in UB Forest management is expected to be able to compete and support economic growth occuring in the growth triangle constellation (golden triangle) in Malang Raya. The model built is a policy model in KHDTK forest management. In addition, the policy model to be built refers to the variables and indicators in the forestry sector of Green Economy theory and is based on the SDGs perspective. This is due to the model to be built is more directed at developing the feasibility of forests economy that can be developed towards business and environmental conservation.

\section{LITERATURE REVIEW}

a. Natural Resources in the Forestry Sector

The current concept of forest sustainability generally has a broader scope than just yield sustainability, which is based on social, economic and ecological aspects. In line with this definition, [1] further states that sustainable forest management, which was initially focused on producing wood and other forest products, is now also actually aimed at encouraging community's welfare, improving environmental quality, preventing environmental damage and rehabilitating the damaged environment due to internal and external factors.

b. Sustainable Development in the Management of Natural Resources

Sustainable development is officially used in MPR Decree No. IV / MPR / 1999 on the guidelines of state policy $(\mathrm{GBHN})$, while the term Sustainable Development with an Environmental Perspective is used in Act No. 23 of 1997 concerning Environmental Management. Until now, the regulation of natural resource management in Indonesia has been implemented since the establishment of the Republic of Indonesia, stated in article 33 paragraph 3 of the UUD 1945, which reads: "The land and water and natural resources contained therein are controlled by the state and used for the prosperity of the people as much as possible" [2].

According to the [24] Brundtland Commission [3], sustainable development is development that covers the needs of the present generation without compromising (reducing) the ability of future generations to meet their needs. In connection with this concept, development in Indonesia cannot not said to be sustainable, because development in Indonesia turns out to have both positive and negative sides. The positive side is the increase of economic growth. Meanwhile, the negative side is the damage to the environment. If the negative impacts of development are not taken into accounts, then economic policies will only benefit in the short term and inflict environmental degradation, as a result of these issues the capacity of natural resources can no longer support society life in the future [1].

c. Determinants of the Implementation of Sustainable

Development

Whether or not the environmentally sound development program is successful in creating sustainable economic development requires the support from several related parties. This is due to the complex economic development problems associated with the environment. The complexity of these problems requires the involvement of all parties, both government, private sector and the whole community. In addition, environmental studies need to involve various (multidisciplinary) experts in social, economic, environmental, legal and political terms.

d. The Concept of Green Economy

The Earth Summit or Rio Conference in 1992 agreed to put environment and development in one context, and has provided direction and provision of multinational institutions to achieve a sustainable future [4]. The definition of a green economy according to Indonesia is: "a development paradigm that based on resource efficiency approach with strong emphasizes on internalizing cost of natural resource depletion on environmental degradation, efforts on alleviate the poverty, creating decent jobs, and ensuring sustainable economic growth" [5].

Several research and modeling results have been conveyed [6], basically showing that green economy initiatives can be implemented without having a negative impact on development goals. Through the implementation of an environmentally friendly economy (greening the economy), potential economic benefits, such as economic growth, employment, and capital will be obtained. In addition, modeling the impact of the carbon tax on the economy shows that the $10 \%$ emission reduction target by 2020 can be achieved without having a negative impact on poverty eradication efforts. Therefore, it can be said that green economy has the potential as a means forward sustainable development. Here's the point of view of the green economy proponents.

e. The Implementation of Green Economy in Forestry Sector

Policies that reflect the implementation of the green economy in the forestry sector can be grouped into policies related to: (i) The contribution of the forestry sector to climate change; (ii) Sustainable forest resource management; and (iii) Other environmental service providers (other than greenhouse gases emissions that cause climate change). The output of this research will be built a green economy model in the management of UB Forest based on the SDGs perspective while still carrying out the functions of the Tri Dharma Perguruan Tinggi. Building a green economy system in UB Forest management with the perspective of SDGs is an alternative in overcoming the challenges of sustainable development which must include three aspects, namely economic, social and environmental. The basic principles that balance the three dimensions are (1) people (humans); (2) 
planet (earth); (3) prosperity; (4) peace and (5) partnership (cooperation). In the principle of people (humans), the role of UB Forest is intended for poverty eradication, community development, development of education \& training as well as a better standard of living. On the principle of planet (earth), the role of UB Forest is intended for carbon absorption and emission reduction, bioenergy provider, environmentally friendly building materials provider and preserving biodiversity. In the principle of prosperity, the role of UB Forest is intended to create new economic growth, increase profits, local and regional development, and support the industrial growth. In the principle of peace, the role of UB Forest is intended to develop peace and open society in maintaining and utilizing forest biodiversity. In the principle of partnership (cooperation), the role of UB Forest is intended to involve various actors or parties in the form of cooperation, collaboration and forest management partnerships. The interrelation of the five fundamental principles balancing economic, social and environmental dimensions is then internalized in policies that reflect the implementation of the green economy in the forestry sector in relation to: (i) The contribution of the forestry sector to climate change; (ii) Sustainable forest resource management; and (iii) other environmental service providers.

\section{f. Soil Infiltration}

On soil that has a coarse texture because it contains a lot of sand, the soil is said to be porous and has high porosity. This means that the soil contains a lot of pores, especially macro pores. Due to the large number of macro pores so that water easily enters the soil, this means that the infiltration is high, when compared to soils that contain lots of dust and clay [7]. Soil organic matter plays a role in changing the percentage of soil porosity, through improving soil structure and stability of soil aggregates. Soil organic matter resulting from the decomposition of remaining vegetation helps in forming soil aggregations to form granules and enlarge the volume of existing pores, so that it tends to reduce the level of soil density and increase the amount of water that can be carried by the soil [8]. Biological activities such as the activity of plant roots and soil organisms affect the formation of soil aggregates. The number of roots increases granulation and microorganism activity which in turn increases soil porosity and soil structure stability. The resulting root and litter system can help increase soil permeability and soil infiltration rate [9].

Physically, soil organic matter plays a role in determining the color of the soil to dark brown, stimulating granulation, reducing plasticity and soil cohesion, improving soil structure to become more crumbly so that soil porosity is higher and the infiltration rate is higher, and increases the power of the soil to hold water so that drainage not excessive, moisture and soil temperature become stable [10]. Initial groundwater content affects soil water infiltration and infiltration rate. In conditions where the groundwater content is initially low, the infiltration rate will be maximum and will decrease with increasing water content [11]. The ability of the soil to store water depends on the porosity of the soil. High porosity, the soil can store large amounts of water, so that the rainwater that comes will be able to absorb or infiltrate quickly without the occurrence of surface runoff [12].

\section{METHODOLOGY}

The method used in this research is qualitative research. The type of study used in this research is phenomenology. In relation to research related to forming a green economy system in UB Forest Management in the Perspective of Sustainable Development Goals (SDGs), the focus of this research is as follows:

1) The management of Forest Area With Special Purpose (KHDTK) UB Forest, include:

a) The planning of KHDTK

b) The implementation of KHDTK activities

c) The partnership of KHDTK management

d) Forest utilization in the KHDTK area

e) Development of supporting facilities and infrastructure for KHDTK

f) Reporting on the management of KHDTK

2) Building a green economy model in the management of UB Forest in the Perspective Sustainable Development Goals (SDGs) in Malang Regency, namely:

a) Regulation and Institutional

b) Protection and management of KHDTK

c) Sustainable funding

d) Institutional-Partnership adjustment

e) Community involvement

f) Green Economy model in the management of UB Forest, consisting of: The concept of contribution policy in the forestry sector related to climate change; The concept of sustainable forest resources management; The concept of environmental service provider,

3) The Achievement of SDGs 15th Goals: Land Ecosystem

In relation with this research, the type of data used is in the form of words / descriptions and actions, written data sources, and photos. The instrument used as a source of information is a person or that can be used as a data source, because it is considered to have mastered the aspect of problem closely related to the implementation of an activity. In relation to this research, the main sources of information in this research are stakeholders or officials related to UB Forest management through informants ranging from UB Forest management, UB academics, forest farmers, local government and village.

In this research, researchers used a sampling technique based on the Snowball Sampling theory. To obtain data objectively and independently in this research, the observation method was used. According to [13] this observation in qualitative research is often referred to as "Participatory Observation". This direct observation will be carried out with an aboveboard observation approach to observe various activities and events that occur in UB Forest management activities, along with social conditions and the surrounding 
environment.

This research carried out in Karangploso sub regency, Malang regency. This is because the location is a Golden Triangle area, consisting of Malang Regency, Malang City and Batu City. The data analysis in qualitative research is a process of systematically tracking and arranging interview transcripts, field notes, and other materials collected to increase understanding of these materials so that the findings can be interpreted to others. At the data analysis stage, the collected data is simplified into a format that is easier to read and understand.

\section{RESULT AND DISCUSSION}

\section{A. The Management of KHDTK UB Forest}

1) The Planning of KHDTK UB Forest

The forest management plan in the UB Forest area which is made will be used as a legal umbrella in future management plans towards everlasting sustainable forest management. Thus, the preparation of the KHDTK UB Forest management plan needs to be done as an implementation guide that will be used as a guideline and reference for forest planning activities and the implementation of the development of forest management plans in the field which aims to bring the institution to its final goals in accordance with the objectives implied in the Vision and Mission of University of Brawijaya [14].

Referring to Rector Regulation No. 2/2020 of University of Brawijaya concerning UB Educational and Training Forest Management, the planning must regard the principles of integration, harmony, benefits of forest preservation and sustainability. Regulation of the Minister of Environment and Forestry of the Republic of Indonesia Number P.15 / MENLHK / SETJEN / KUM.1 / 5/2018 Concerning Forest Areas With Special Purposes in article 14 paragraph (1) states that KHDTK planning is carried out through the activity of forest inventorization, area arrangement and the preparation of management plan.

\section{a. Forest Inventorization}

Forest inventorization in the planning of KHDTK aims to see the condition of the forest and its environment in the KHDTK area. In its implementation, UB Forest has carried out a forest inventorization. Forest inventorying activities in the UB Forest area are carried out by collecting data on the conditions of the biophysical potential contained in it, both biotic components and abiotic components. Biotic components consist of animals, plants and humans.

\section{b. Area Arrangement}

The second activity that must be carried out in the planning of KHDTK UB Forest is area arrangement. The arrangement of KDHTK UB Forest area is carried according to the results of forest inventorization. The arrangement of KDHTK UB Forest area which is $541 \mathrm{Ha}$ also considers the slope class and forest function division of management space.

c. Arrangement of Management Plan

The arrangement of KHDTK UB Forest management plan is carried out according to the results of the inventorization and area arrangement. Fundamentally, UB Forest management already has a policy which is stated in the long term, medium term and short term management plan. So that the commitment and political will of UB Forest managers in the arrangement of Forest Area Management Plan Documents (RPKH) must be improved. Especially in this case in the improvement and legalization of the Draft of Management Plan for KHDTK UB Forest into a Documents of Management Plan for KHDTK UB Forest, it must be implemented immediately. Because if the management planning document is not arranged immediately there will be administrative and legal sanctions that will be imposed on the forest manager.

\section{2) The Implementation of KHDTK UB Forest Activities}

KHDTK UB Forest is a forest with the educational and training purpose so that in the implementation of KHDTK UB Forest activities, it must be based on KHDTK activities for forestry research \& development, KHDTK for forestry education \& training as well as religious and cultural activities. KHDTK UB Forest as an educational forest is research \& development, training and religious and cultural activities carried out in the production forest area in UB Forest become a means of direct learning (field laboratory) for related study programs to conduct research and learning activities supported by adequate laboratory space. The development of educational facilities and infrastructure, both in quantity and quality, is absolutely necessary in order to provide quality education services to produce graduates who have competence and are able to compete in the labour market. Especially in order to improve the accreditation status and attract more student candidates, the adequacy of educational facilities and infrastructure needs to be considered and prioritized for its development [15].

a. Implementation of KHDTK Activities in the Forestry Research \& Development

In the implementation of KHDTK of Research \& Development activities which have been carried out based on the 2017 KHDTK UB Forest Annual Report, the research topics carried out by University of Brawijaya students at UB Forest include: 1) coffee root studies, 2) soil fertility inventory, 3) ecology (epiphytic plant diversity and invasive alien species plants), and 4) studies on the feasibility and the active role of UB Forest community in ecotourism. Whereas the research topic carried out by the lecturer is more focused on the inventory of the biophysical, social and economic conditions of the community in UB Forest. Some special research is carried out in the UB Forest protected area in an effort to identify the damage to ecological functions in the protected forest area which is then used as a basis in determining the appropriate management action for the UB Forest protected area.

b. Implementation of KHDTK Activities in the Forestry Education \& Training

In the implementation of KHDTK activities in the Forestry 
Education \& Training carried out by the academic community of University of Brawijaya (Students and Lecturers), based on the 2017 KHDTK UB Forest Annual Report, students who do practicum activities at UB Forest which are carried out by undergraduate students (Agroecotechnology, Agribusiness study program). The implementation of KHDTK activities in the Forestry Education \& Training is also by practicum activities carried out by students at UB Forest, namely field work practices, work internships, and on the job training $(\mathrm{KKN})$. Field work practice activities and student work internships in actual agricultural activities at UB Forest such as Balsa tree nurseries, coffee plant conservancy, and post harvest coffee. UB Forest is also used for non-academic activities of UB students. Non-academic activities carried out at UB Forest including: 1) A series of orientation for the VII Field Agroecotechnology study program (Chain); 2) 2017th Soil Science Olympiad; 3) organization training and upgrading carried out by the Student Executive Board (BEM) of the Faculty of Animal Husbandry; and 4) Research camp carried out by students from the Faculty of Administrative Sciences [16].

3) Development of Supporting Facilities and Infrastructure for KHDTK UB Forest

The development of supporting facilities and infrastructure for KHDTK UB Forest is one of the most important needs to support all forest management activities in it. The development of supporting facilities and infrastructure for KHDTK UB Forest was carried out in three sub villages, namely Sumberwangi sub-village of Donowarih village, Sumbersari sub-village of Tawangargo village, and Buntoro sub-village of Ngenep village. The development of supporting facilities and infrastructure for KHDTK UB Forest is a very important thing to do. This is because the development of these facilities is an effort to facilitate the access for UB Forest management. The basic facilities that must be fulfilled are road access, water and electricity. The three facilities have to be properly built in all areas of UB Forest. However, these three things are still an obstacle in the treatment of UB Forest.

\section{4) Reporting on the Management of KHDTK UB Forest}

According to the Regulation of the Minister of Environment and Forestry of the Republic of Indonesia Number P.15 / MENLHK / SETJEN / KUM. 1 / 5/2018 in article 26 related to reporting on the management of KHDTK must be carried out by KHDTK managers by compiling reports on KHDTK management periodically every 1 (one) year and submitted to the Minister. The reporting on the management of KHDTK UB Forest has been carried out by the manager by making a document for the 2017 KHDTK UB Forest Annual Report. The document reports the results of the achievements in the forest management master plan. According on that statement, it appears that the weakness of UB Forest management is related to the drafting of planning and reporting documents. In addition, when referring to Rector Regulation No. 2/2020 of the University of Brawijaya, it is stated that the monitoring and evaluation of the management of KHDTK UB Forest is carried out by Academic Entities of University of Brawijaya and / or institutions or special organizations appointed to conduct monitoring and evaluation, which includes evaluation of planning, management, and evaluation of the implementation of UB Education \& Training Forest management. Thus, political will and employee commitment need to be improved. Because the two documents are official documents that must be fulfilled as guidelines and accountability for the management of KHDTK UB Forest.

\section{B. Green Economy Model}

1) The Concept of Contribution Policy of the Forestry Sector to Climate Change

The role of forests in contributing to climate change itself is specified in Forestry Law No. 41/1999 and its amendments, namely Law no. 19/2004, including carbon absorption efforts which are the utilization of forest environmental services. Technically, carbon absorption has been regulated in Forestry Minister Regulation No. P.36 / Menhut-II / 2009 concerning Licensing Procedures for Utilization of Carbon Absorption and / or Carbon Storage in Production Forests and Protected Forests issued as implementation of regulations from Article 33 paragraph (1) of Government Regulation No. 6/2007 in conjunction with PP No. 3/2008 concerning Forest Management and Forest Management Planning, and Forest Utilization, in which one of the clauses states that: "one form of environmental service utilization in production forests and protected forests is carbon absorption and / or storage." UB forest with areas of production forest and protected forest with stands of pine and mahogany trees can contribute to maintaining the climate and weather in the surrounding area.

2) The Concept of Sustainable Forest Resources Management

The concept of sustainable forest resource management can be stated in the Sustainable Forest Management (PHL) model. PHL is an important part of the green economy of the forestry sector. Forest preservation will only be achieved if forest management is carried out properly. In accordance with Law Number 4/1999 concerning Forestry, article 10 paragraph 2, forest management consists of: a) Forestry planning; b) Forest management; c) Research \& development, education \& training, and forestry socialization, and d) Supervision. Sustainable forest management is developed through various efforts, including: (i) Reinforcement of forest management units; (ii) Implementation of a timber certification system; and (iii) Reforestation of forest areas, restoration of degraded forests and development of community forests; (iv) Development of of forest plantations.

3) The Concept of Environmental Service Provider

The utilization of environmental services in protected forests and production forests in the KHDTK area can be in the form of natural tourism businesses, water utilization businesses, sources of biodiversity, and carbon trading businesses. In KHDTK UB Forest, the form of environmental services carried out is in the form of natural tourism businesses and can also be developed in the direction of carbon trading business. 
4) The Achievement of SDGs 15th Goals: Land Ecosystem

In its implementation, UB Forest with the aim of being an education $\&$ training forest consisting of protected forest areas and production forests area also contributes to the achievement of SDGs target related to forests based on United Nation indicators. First, the Management Plan of KHDTK UB Forest has been directed at sustainable management with regards to economic, social and environmental aspects. In addition, the fundamental thing that must be carried out in this sustainable management is sustainable funding and compatible institutions. Second, in the implementation of KHDTK UB Forest management, efforts to eradicate deforestation by individuals and community groups. This endeavor carried out by the KHDTK manager by increasing efforts to protect and monitor forests. Because with the KHDTK status, UB Forest is not allowed to cut down tree stands carelessly, except for management purposes in training and research \& development activities and with the permission of the Minister of Environment and Forestry which is carried out in accordance with the provisions of the related laws and regulations. Third, UB Forest Management also makes efforts to restore forest degradation by reforestation and forest rejuvenation, especially on dry land caused by forest fires and other disasters. Thus, the existence of UB Forest has a role in the achievement of the SDGs indicator in goal $15 \mathrm{th}$. The three achievements of the 15th goal of SDGs target carried out by UB Forest managers are inseparable from multi-disciplinary aspects with pentaple bottomline which is the basic principle that balances economic, social and environmental aspects known as the 5Ps, namely profit, people, planet, penotechnology, and prophets [22], [23], [24].

\section{Soil Infiltration}

Soil texture shows the composition of the particles that make up the soil which is expressed as a relative proportion (\%) of the fractions of sand, dust and clay [9]. From the results of soil texture analysis, it can be seen that the highest percentage is dust, the distribution pattern of the top layer texture in the dust fraction has a percentage of $40-54 \%$, sand is $25-41 \%$ and clay is $16-21 \%$. The lower layer has a texture distribution in the dust fraction which has a percentage of 47 $54 \%$, sand is $22-34 \%$ and clay is $13-31 \%$. The upper layer has a higher sand fraction, while the lower layer has a higher dust and clay fraction. The texture distribution pattern in the UB Forest area still has the same soil texture, namely dusty loam. According to [17] the UB Forest area has the geology of Arjuna Welirang Volcanic (QVAW) which is in the arjuno welirang young quaternary mountain formation, the amount of ash and sand in the volcanic area over time causes the texture class obtained by dusty clay with dust conditions that are still high around 50\%.

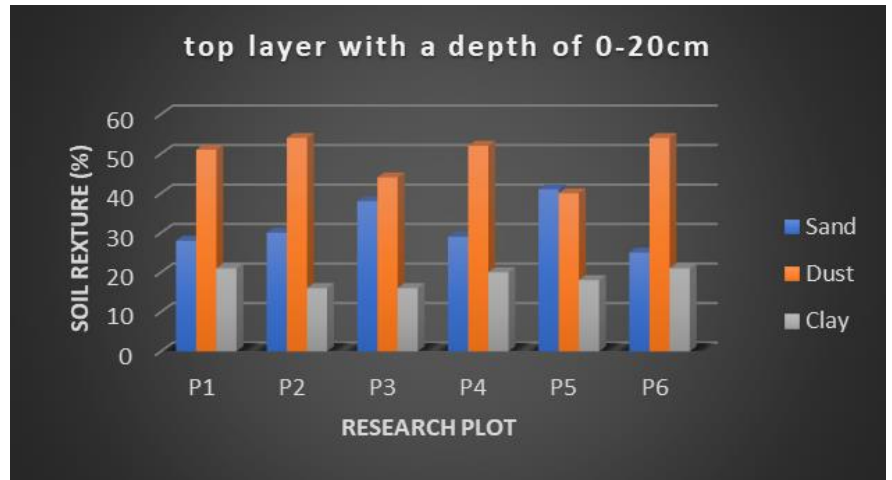

(a)

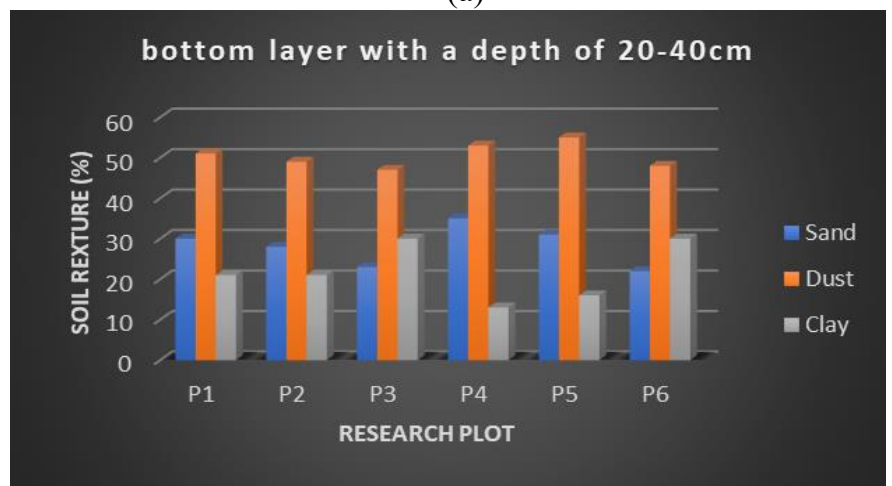

(b)

Figure 1. Soil texture at the top layer with a depth of 0-20 $\mathrm{cm}$ (a) and the bottom layer with a depth of 20-40 cm (b). Description: P1 (Protected Area); P2 (Mahogany + Coffee); P3 (Meeting Pine + Coffee); P4 (Pine enough + Coffee); P5 (tenuous pine + coffee); P6 (Pine + annual)

Organic matter is a non-mineral fraction found as the building blocks of soil. Organic material is usually a heap of dead plant, animal or micro-organism tissue and some of it has undergone renovation [18]. From the results of the analysis of organic matter, in general all research plots had a percentage of organic matter above $4 \%$. In all research plots the upper layer has a higher percentage of organic matter than the lower layer, the upper layer has a percentage of organic matter $8.3 \%$ - $11.8 \%$ and the lower layer $4 \%-8.7 \%$, this is due to the source material organic, namely plant litter accumulating in the top layer of the soil, making the organic matter in the top layer higher and then the organic material going down to the subsoil through leaching of water that enters the soil [19].

The P1 plot has the highest percentage of organic matter in the upper and lower layers than the other plots, while the lowest percentage of organic matter in the upper layer is found in the P5 plot and the lower layer is in the P6 plot. This could be because the source of organic matter derived from plant litter has a greater amount than the other plots. Litter is a source of organic matter, the more plant litter, the higher the organic matter [20]. In the P3 plot, even though it has a lot of litter than the other plots, but organic matter is lower than in the P1 plot, this can be because the P3 plot has litter that comes from only one plant species, namely from pine plants that have litter quality. slower weathered. In P1 it is a protected area which is thought to have litter quality that is 
easily decayed. Litter that is easily decomposed is due to mixed litter that comes from various plants, compared to litter which is only one plant species such as pine and mahogany production forests which have litter quality that is slower to rot [21]. Pine litter is also included in the slow weathering category, many types of litter on the surface of the soil which are categorized as difficult to rot will accumulate longer than the types of litter that are easily weathered and quickly decomposed by microorganisms.

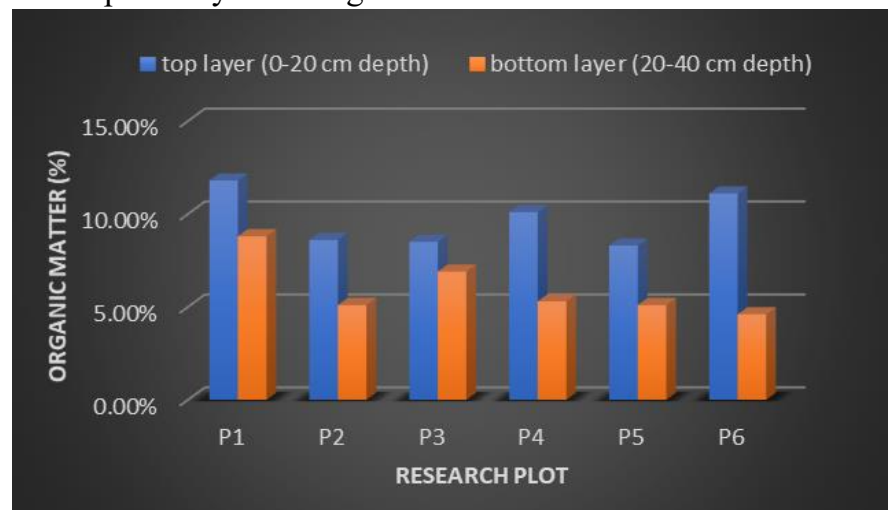

Figure 2. Organic material in the upper and lower layers of the six research plots. Description: P1 (Protected Area); P2 (Mahogany + Coffee); P3 (Meeting Pine + Coffee); P4 (Pine enough + Coffee); P5 (tenuous pine + coffee); P6 (Pine + annual)

In the analysis of soil bulk density, in general, the weight of the top layer and the bottom layer ranged from 0.63 to 0.93 $\mathrm{gr} / \mathrm{cm} 3$. In general, the trend of density values from the top layer to the bottom layer has decreased, except for plots P5 and P6. This is because the organic material in the upper layer is high. The $\mathrm{P} 2$ plot has the highest content weight value with an average of $0.92 \mathrm{gr} / \mathrm{cm} 3$, while the lowest weight value is found in the P1 plot with an average of $0.66 \mathrm{gr} / \mathrm{cm} 3$. The general density of the upper and lower layers ranges from 2.2 $2.5 \mathrm{~g} / \mathrm{cm} 3$. The value of the specific gravity of each research plot has a value that is not too far away, this can be due to the soil texture in the area is also relatively the same, namely dusty loam. In general, the density of mineral soils has a value of 2.5 - $2.7 \mathrm{~g} / \mathrm{cm} 3$, while the research plot has a lower value. The value of bulk density and soil density are influenced by organic matter. Organic matter can reduce the value of soil density and density, according to [18]. Low density is due to high organic matter, the higher the organic matter in the soil, the lower the density and density of soil content.

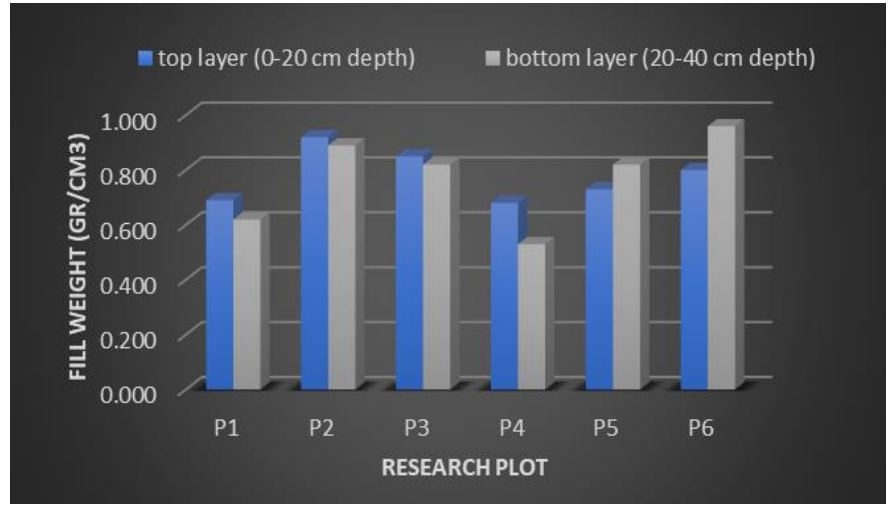

(a)

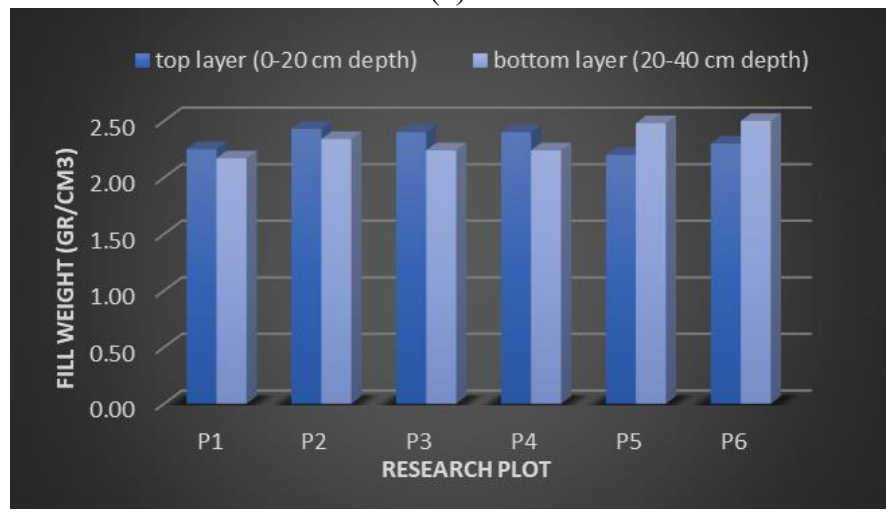

(b)

Figure 3. Fill weight (a) and density (b) of the top and bottom layers of soil in the six research plots. Description: P1

(Protected Area); P2 (Mahogany + Coffee); P3 (Meeting Pine + Coffee); P4 (Pine enough + Coffee); P5 (tenuous pine + coffee); P6 (Pine + annual)

\section{CONCLUSION}

Based on the analysis that has been conducted it can be concluded that the model of green economy system in the management of UB Forest based on the Perspective of Sustainable Development Goals (SDGs) in Malang Regency consists of a regulatory and institutional system; protection and management of KHDTK; sustainable funding; reinforcement of institutional partnerships; community involvement and implemented in a green economy model. The implementation of green economy model in the management of KHDTK UB Forest in the concept of contribution of forestry sector related to climate change; the concept of sustainable forest resource management; and the concept of environmental service providers. By implementing the green economy model in the management of KHDTK UB Forest. Thus, the existence of UB Forest has a role in the achievement of the SDGs indicator on the 15th goal. The three achievements of the SDGs target of the 15th goal carried out by UB Forest managers is inseparable from the multi-disciplinary aspect with the pentaple bottomline which becomes the basic principles that balance economic, social and environmental aspects known as the 5Ps, namely profit, people, planet, penotechnology, and prophets. The results of infiltration measurements using the single ring infiltrometer method can better describe the infiltration that 
occurs in the soil. The highest soil infiltration is found in protected areas with a soil infiltration rate of $131.33 \mathrm{~cm} /$ hour (single ring infiltrometer). Meanwhile, the lowest infiltration was found in pine production forest plots intercropped with annual crops with a soil infiltration rate of $12 \mathrm{~cm} /$ hour (single ring infiltrometer).

\section{LIMITATIONS OF THE STUDY AND FUTURE RESEARCH}

The utilization of the KHDTK UB Forest area which consists of production forest area and protected forest area, is only limited to the utilization of non-timber forest products. This is one of the obstacles that then the manager of KHDTK UB Forest cannot utilize timber forest products, as a source of funding in forest management. So that with the green economy model, the implementation of the carbon market is expected to be able to utilize forest resources to have economic value and be environmentally friendly. So the researcher's suggestion for further research is to carried out research related to the method of calculating stored carbon in the solidified biomass contained in KHDTK UB Forest and then looking for networks for private companies or industries to carry out the mechanism of carbon trading.

\section{ACKNOWLEDGMENT}

This study was supported by all authors / co-authors registered for approval during the study, data analysis and interpretation, and revision of the manuscript. This research aims to improve knowledge during doctoral education. This research did not get financial assistance from any party.

\section{References}

[1] Lewoema, Z.K. 2008. Kelestarian Hutan Di Indonesia, Tanggungjawab Setiap Warganegara. WALHI. Jakarta.

[2] Maryunani, 2018. Pengelolaan Sumber Daya Alam dan Pembangunan Ekonomi Secara Berkelanjutan. Malang: UB Press.

[3] World Commission on Environment and Development (WCED). 1987. Our common future. Oxford University Press, South Melbourne.

[4] United Nations Environmental Programme (UNEP). 2011a. Towards a Green Economy: Pathways to Sustainable Development and Poverty Eradication - a Synthesis for Policy Makers.

[5] United Nation on Environment Program (UNEP). 2011. Toward a Green Economy: Pathways to Sustainable Developpement and Poverty Eradication.

[6] Yusuf, Arief Anshori. 2012. Green Economy in Indonesia and the role of economic Instruments. Disampaikan pada Seminar Ekonomi Hijau. Bandung, 14 Mei 2012. Kerjasama Kementerian PPN/Bappenas dan LP3E FEBUNPAD.

[7] Banuwa, I. S. 2013. Erosi. Kencana Prenada Media Grup. Jakarta.
[8] Sofyan, M. 2006. Pengaruh Berbagai Penggunaan Lahan terhadap Laju Infiltrasi Tanah. Skripsi. Program Studi Ilmu Tanah, Fakultas Pertanian IPB. Bogor.

[9] Asdak. 2002. Hidrologi dan Pengelolaan Daerah Aliran Sungai. Gadjah Mada University Press. Yogyakarta.

[10] Hanafiah, K.A. 2005. Dasar-dasar Ilmu Tanah. Penerbit PT Raja Grafinda. Persada. Jakarta.

[11] Arsyad, S. 2010. Konservasi Tanah dan Air. UPT Produksi Media Informasi Lembaga Sumberdaya, IPB. Bogor Press.

[12] Suryatmojo, H. 2006. Peran Hutan Sebagai Penyedia Jasa Lingkungan. Fakultas Kehutanan Universitas Gadjah Mada. Yogyakarta.

[13]H.B. Sutopo. 2002. Pengantar Penelitian Kualitatif. Surakarta: Universitas Sebelas Maret Press

[14] Universitas Brawijaya. 2017. Laporan Tahunan UB Forest Tahun 2017.

[15] University of Brawijaya. 2020. Draft of Management Plan for UB Forest.

[16] Santosa, S. dan T. Suwarti. 1992. Lembar Geologi Malang, Jatim. Pusat Penelitian dan Pengembangan Geologi. Bandung.

[17]Raharjo, R. 2006. Studi terhadap Produksivitas Serasah, Dekomposisi Serasah, Air Tembus Tajuk dan Aliran Batang serta Leaching pada beberapa Kerapatan Tegakan Pinus (Pinus merkusii), di Blok Cimenyan, Hutan Pendidikan Gunung Walat, Sukabumi.

[18] Hakim, N., M.Y. Nyakpa, A.M. Lubis, S.G. Nugroho, M.A. Diha, G.B. Hong, and H.H. Bailey. 1986. DasarDasar Ilmu Tanah. Universitas Lampung. Lampung.

[19] Safriani, H., R. Fajriah, S. Sapnaranda, S. Mirfa, M. Hidayat. Estimasi Biomassa Serasah Daun Di Gunung Berapi Seulawah Agam Kecamatan Seulimuem Kabupaten Aceh Besar. Prosiding Seminar Nasional Biotik 2017. Banda Aceh.

[20] Devianti, Ory K. A., and Tjahjaningrum Indah T. D. 2017. Studi Laju Dekomposisi Serasah Pada Hutan Pinus Wisata Taman Safari Indonesia II Jawa Timur. Jurnal Sains dan Seni ITS. Vol.6 No.2, 2337-3520.

[21] Sukoharsono, Eko Ganis. 2018. Strategies to Improve the Sustainability in Promoting Transparency, Accountability and AntiCorruption: An Imaginary Dialogue. The International Journal of Accounting and Business Society, Vol 26, No 1 (2018).

[22] Brundtland, G.H., editor. 1987. Report of The World Commission on Environment and Development, The United Nation.

[23] Gulnara N. Nabiyeva, Stephen M. Wheeler, Geographic Information Systems as a Tool to Support the Sustainable Development Goals, Engineering World, Volume 2, 2020, pp. 219-226

[24]Zhixiang Zhang, Jon Bryan Burley, Trisha Machemer, Rex L. LaMo, Post-Industrial Redevelopment Site Design Reclamation in Shanghai, People's Republic of China, Engineering World, Volume 3, 2021, pp. 6-23 
Creative Commons Attribution License 4.0 (Attribution 4.0 International, CC BY 4.0)

This article is published under the terms of the Creative Commons Attribution License 4.0

https://creativecommons.org/licenses/by/4.0/deed.en_US 